\title{
Introduction to Volume 42
}

Barnboken: Journal of Children's Literature Research is the only Swedish academic journal dedicated to children's and young adult literature. In recent years the journal has developed and expanded, and in 2019 Barnboken published an unprecedented number of articles for the second year in a row. A total of 16 articles were published within three larger themes, as well as 18 reviews of Nordic and international theoretical literature. During the past year, we have also been pleased to see a record-breaking number of subscribers signing up for the journal's alerts.

The first of this year's three themes was "Money," edited by Lydia Wistisen (PhD), Stockholm University. The seven articles within the theme address how children's and young adult literature deals with economic and social structures, and what role issues related to money play in stories for young readers. The authors analyse a wide range of material and cover a long time period, from the portrayal of children as consumers in the Danish children's magazine Ungdommens Ven (The Friend of Youth, 1770) to depictions of child poverty, homelessness, and begging in contemporary Swedish picturebooks. As Wistisen notes in her introduction, the contributions as a whole demonstrate both continuity and change in how the writers and illustrators approach financial issues for children and youth.

The second theme, "Radical Children's Literature," includes six articles and was edited by Professor Elina Druker, Stockholm University. The articles within the theme examine how children's literature through form, message, and/or content challenges norms and conventions both inside and outside the literary universe. These articles are based on presentations made at an international conference on the topic arranged at Stockholm University in November 2018. In her introduction, Druker states that the radical potential of children's literature always depends on the ideological, social, pedagogical, and artistic ideas of the time. This is clearly shown in the six articles which, among other things, contextualize Russian avantgarde picturebooks and German interwar poetry.

As managing editor I was in charge of the third theme, "Swedish Translations of L.M. Montgomery's Anne and Emily Books." It con-

(C2020 Åsa Warnqvist. This is an Open Access article distributed under the terms of the Creative Commons Attribution-Noncommercial 3.0 Unported License (http://creativecommons.org/ licenses/by-nc/3.0/), permitting all non-commercial use, distribution, and reproduction in any medium, provided the original work is properly cited.

Citation: Barnboken - tidskrift för barnlitteraturforskning/Journal of Children's Literature Research, Vol. 42, 2019

http://dx.doi.org/ 10.14811/clr.v42i0.501 
sists of three articles that examine the Swedish translations of Canadian author Lucy Maud Montgomery's novels about Anne of Green Gables and Emily of New Moon. The articles take a closer look at the translation practices at the time the translations were made, and the effects of these practices on the versions of Montgomery's texts that Swedish readers encounter. For example, changes and omissions show that the views on girls and girls' reading at the time of the translations have resulted in that the female characters are described as more conventional and as having a more limited scope of action than the author originally intended.

All of this year's themes have included an article written by the editor in charge. In these cases, the articles have been handled by a member of the editorial board who also has administered the peer review process. Lydia Wistisen's article was edited by Olle Widhe, Elina Druker's by me, and my contribution was edited by Maria Jönsson.

Barnboken's articles and reviews are published online under Open Access, and they are available free of charge on the journal's website as well as in fulltext versions through several large international databases. The main focus of the journal is Swedish and Nordic material, but we have readers all over the world. During 2019, my fellow members of the editorial board consisted of Maria Jönsson (Associate Professor, Umeå University, Sweden), Anne Skaret (Professor, Inland Norway University of Applied Sciences, Norway), Olle Widhe (Associate Professor, Gothenburg University, Sweden), Björn Sundmark (Professor, Malmö University, Sweden), and Mia Österlund (Associate Professor, Åbo Akademi University, Finland). Review editor during 2019 was research assistant Hanna Liljeqvist (the Swedish Institute for Children's Books). The journal's international advisory board includes 15 prominent Swedish, Nordic, and international scholars. The journal is published with financial support from the Swedish Research Council, and since a few years back the journal is also awarded annual support from the NOS/HS.

\section{Åsa Warnqvist Managing Editor of}

Barnboken: Journal of Children's Literature Research and Research Manager of the Swedish Institute for Children's Books 